\title{
Assessment of Onion Varieties for Late kharif in North-Eastern Coastal Plain Zone of Odisha
}

\author{
Biswanath Sahoo $^{1 *}$, M. Nedunchezhiyan ${ }^{2}$, Suchismita Tripathy ${ }^{3}$, \\ Kishore Sahoo ${ }^{4}$, Rituparna Munshi ${ }^{5}$ and Madhuri Toppo ${ }^{6}$ \\ ${ }^{1}$ Krishi Vigyan Kendra (OUAT), Bhadrak, Ranital-756111, Odisha, India \\ ${ }^{2}$ Regional Centre of Indian Council of Agricultural Research-Central Tuber Crops Research \\ Institute, Bhubaneswar-751019, Odisha, India \\ ${ }^{3}$ Department of Agronomy, College of Agriculture (OUAT), \\ Bhubaneswar-751003, Odisha, India \\ ${ }^{4}$ RRTTS, Keonjhar (OUAT) -758002, Odisha, India \\ ${ }^{5}$ Department of Horticulture, Institute of Agricultural Science, University of Calcutta, \\ Kolkata-700019, West Bengal, India \\ ${ }^{6}$ Krishi Vigyan Kendra (OUAT), Jharsuguda-768212, Odisha, India \\ *Corresponding author
}

\section{A B S T R A C T}

\begin{tabular}{|l|}
\hline K e y w o r d s \\
On farm testing, \\
Varietal evaluation, \\
Disease reaction, \\
Economics, \\
Farmers preference \\
\hline Article Info \\
\hline $\begin{array}{l}\text { Accepted: } \\
\text { 18 August } 2020 \\
\text { Available Online: } \\
\text { 10 September } 2020\end{array}$ \\
\hline
\end{tabular}

Onion (Allium cepa L.) is one of the important commercial spice crop grown in India for its varied utilization in different cuisines. Odisha produces less than $20 \%$ of its consumption needs and for the rest it has to depend on imports from other states. The production and productivity of onion mainly depends upon its genotype, edaphic and climatological factors. Due to high domestic need in Bhadrak district which can't be augmented due to non-availability of high yielding varieties particularly in late kharif season. Hence, Krishi Vigyan Kendra, Bhadrak, Ranital (OUAT) conducted an On Farm Testing (OFT) for late kharif during the year 2015-16 and 2016-17 season on farmers field of the villages viz. Kunarda, Shologaon, Rajualibindha, Miriga and Baranga to evaluate the field efficacy of the late kharif varieties. From the on farm testing it was revealed that the onion variety performed better in yield as well as in growth parameters in compared to the N-53 and Agrifound dark red. The consumer preference was more in case of Bhima Super variety for its high shelf-life and fetches higher price in the market. Bhima Super variety registered $43.21 \%$ increased yield over Agri found Dark Red variety.

\section{Introduction}

Onion (Allium cepa L.) is the most important spice crop grown in Odisha for its diverse use. Onion is the largest spice vegetable produced and consumed not only in India, but also in the world. Although it is classified as vegetable it has special qualities, which add to taste and flavour to a crop of National importance. The annual production of onion 
in Odisha has reached 4.19 lakh MT during the year 2011-12. The average productivity of Odisha was $11,920 \mathrm{~kg} / \mathrm{ha}$ in comparison to the National average of $15,106 \mathrm{~kg} / \mathrm{ha}$. In Odisha, the highest productivity is $14,375 \mathrm{~kg} / \mathrm{ha}$ has been recorded in Bolangir district. Horticultural activities invariably improved the economic status of farmers. In the past, plenty of evidences explain that prices of onion skied during October - January due to spoilage of Kharif onion owing to vagaries of monsoon.. The erratic and untimely rains damaged the Kharif, late Kharif crop as well as Rabi onion nursery. Hence, to obtain sustainable income from Kharif onion and minimization of price fluctuation in onion market, farmers ${ }^{\text {ee }}$ needs to adopt proper soil management practices. Water-logging is one of the major abiotic stresses that severely limits onion productivity. In onion, bulb size and yield are the economically important parameters that are getting seriously hampered due to frequent flooding events during Kharif season. So, suitable varieties are not available for cultivation during kharif season. Shah et al., (2012) also observed that the varietal differences among onion varieties arose due to genetic variability.

\section{Materials and Methods}

The present study was carried out for two years by Krishi Vigyan Kendra (OUAT), Bhadrak, Ranital during late kharif $\left(1^{\text {st }}\right.$ fortnight of the September) of 2015-16 and 2016-17 in the farmers field of the five villages viz. Kunarda, Shologaon, Rajualibindha, Baranga and Miriga. Three improved varieties along with the check variety were evaluated in an area of 0.4 ha. The detail description of the varieties has been enunciated in the Table 1. Initially seeds were subjected to seedling raising in the polyhouse, then after attaining transplantable stage viz. 45-60 days after sowing the seed in the seed bed, the seedlings were distributed to the beneficiaries of the OFT programme. All the recommended package of practices was adopted from the Directorate of Onion and Garlic Research, Pune, Maharashtra for all the varieties to relish a good crop. The soil type of the adopted village is clay loam soil with medium Nitrogen and Phosphorous, deficient in Potassium and low in organic carbon. Twenty plants were randomly selected from each entry to record the observations on growth, yield, quality parameters, pest and disease incidence.

The bulb yield was accounted on plot basis. Economics of onion was worked out based on the current market price of inputs and outputs. The mean data collected on various aspects over the years were subjected to standard statistical analysis to know the economic feasibility of the technology. The stemphylium blight and purple blotch incidence was by the formula given by Wheeler (1969) which was used to calculate the per cent disease index (PDI).

$$
\text { PDI for severity }=\frac{\text { Sum of all disease ratings }}{\text { Total no. of leaves X Max.rating value }}
$$

Disease ratings were given on the following 0-5 scale (Sharma, 1986). The crop was observed for both onion thrips as well as purple blotch disease at 15 days intervals commencing from 30 days after transplanting. The varieties were further placed in different categories based on their resistance or susceptibility reaction according to scoring as described in Table 2.

According to the scale described by Singh (2004) per cent of the surface of the leaf affected was determined. The infection on leaves was graded in 0-9 scale on the basis of severity/intensity/incidence of infection on leaves (Table 3). The disease incidence was calculated with percentage ratio of infected area with the total area of leaf. 
According to the scale described by Singh (2004) per cent of the surface of the leaf affected was determined. The infection on leaves was graded in 0-9 scale on the basis of severity/intensity/incidence of infection on leaves. The disease incidence was calculated with percentage ratio of infected area with the total area of leaf.

\section{Results and Discussion}

As per perusal of data envisages that, onion varieties had profound effect on growth and quality parameters (Table 4 and 5). The higher marketable bulb yield was observed in Bhima Super variety $(401.0 \mathrm{q} / \mathrm{ha}$ ) followed by Agrifound Dark Red (280q/ha) and N-53 (133 $\mathrm{q} / \mathrm{ha})$. Increase in yield of $\mathrm{N}-53$ improved varieties over Bhima Super and Agrifound Dark Red is $43.21 \%$ and $110.52 \%$ respectively. Such superior variety was mainly due to higher growth and yield parameters like plant height $(55.25 \mathrm{~cm})$, number of leaves per plant (6.45), leaf diameter $(1.15 \mathrm{~cm})$, bulb diameter (polar$44.33 \mathrm{~mm}$ and equatorial-46.72 $\mathrm{mm}$ ). The variations in bulb yield of different varieties of onion also been reported from several places. The superiority and higher yield of Bhima Super was reported by Kerure et al, (2016) in Karnataka, Lawande et al., (2011) in Maharashtra and Tripathy et al, (2013) in Odisha condition. Besides these growth and yield parameters, Bhima Super variety recorded the lowest pest incidence (Thrips, $14.30 \%$ ) and disease incidence (purple leaf blotch, $14.23 \%$ and stemphylium blight, $15.73 \%)$ compared to N-53 and Agrifound Dark Red (Table 6).

Table.1 Details of varieties evaluated during late kharif

\begin{tabular}{|l|l|l|l|l|}
\hline Sl.no & Technological Options & Entries & Source & Year of release \\
\hline $\mathbf{1}$ & TO1: Farmer Practice & N-53 & MPKV, Rahuri & 1990 \\
\hline $\mathbf{2}$ & TO2: Recommended practice & Bhima Super & DOGR, Pune & 2009 \\
\hline $\mathbf{3}$ & TO3: Recommended practice & Agrifound Dark Red & NHRDF, Nasik & 1987 \\
\hline
\end{tabular}

Table.2 Scale for categorizing the varieties against the stemphylium blight of onion

\begin{tabular}{|l|l|l|}
\hline Score & Disease severity (\%) & Disease reaction \\
\hline $\mathbf{0}$ & $<5$ & Immune (I) \\
\hline $\mathbf{1}$ & $6-10$ & Resistant (R) \\
\hline $\mathbf{2}$ & $11-20$ & Moderately Resistant (MR) \\
\hline $\mathbf{3}$ & $21-40$ & Moderately Susceptible (MS) \\
\hline $\mathbf{4}$ & $41-60$ & Susceptible (S) \\
\hline $\mathbf{5}$ & $>60$ & Highly Susceptible (HS) \\
\hline
\end{tabular}

Table.3 Scale for categorizing the varieties against the purple blotch of onion

\begin{tabular}{|c|c|c|}
\hline Sl.No. & Percent leaf area covered & Grade $(\mathbf{X})$ \\
\hline $\mathbf{1}$ & 2 & 0 \\
\hline $\mathbf{2}$ & 1 & 1 \\
\hline $\mathbf{3}$ & $2-10$ & 3 \\
\hline $\mathbf{4}$ & $11-25$ & 5 \\
\hline $\mathbf{5}$ & $26-50$ & 7 \\
\hline $\mathbf{6}$ & $50>$ & 9 \\
\hline
\end{tabular}


Table.4 Biometric parameters of different varieties of onion in the trial

\begin{tabular}{|c|c|c|c|c|c|c|c|c|c|c|}
\hline \multicolumn{11}{|c|}{ Technology Options } \\
\hline Sl. & \multirow[t]{2}{*}{ Parameters } & \multicolumn{3}{|c|}{$\mathrm{N}-53$} & \multicolumn{3}{|c|}{ Bhima Super } & \multicolumn{3}{|c|}{ Agrifound Dark Red } \\
\hline no & & $2015-16$ & 2016-17 & Mean & $2015-16$ & $2016-17$ & Mean & $2015-16$ & $2016-17$ & Mean \\
\hline 1 & Plant height $(\mathrm{cm})$ & 51.97 & 49.78 & 50.87 & 54.32 & 56.18 & 55.25 & 46.58 & 48.22 & 47.40 \\
\hline 2 & No. of leaves/plant & 6.47 & 5.91 & 6.19 & 6.22 & 6.68 & 6.45 & 6.12 & 6.54 & 6.33 \\
\hline 3 & Pseudostem length $(\mathrm{cm})$ & 3.18 & 3.26 & 3.22 & 5.12 & 5.38 & 5.25 & 5.31 & 3.98 & 4.64 \\
\hline 4 & Leaf diameter $(\mathrm{cm})$ & 1.02 & 1.01 & 1.01 & 1.16 & 1.14 & 1.15 & 1.14 & 1.18 & 1.16 \\
\hline 5 & Polar diameter $(\mathrm{mm})$ & 35.11 & 33.16 & 34.13 & 46.22 & 42.38 & 44.33 & 43.35 & 39.16 & 41.25 \\
\hline 6 & Equatorial diameter (mm) & 38.12 & 34.18 & 36.15 & 49.14 & 44.38 & 46.72 & 45.55 & 39.88 & 42.71 \\
\hline 7 & Days to harvest (DAT) & 92 & 100 & 96 & 118 & 116 & 117 & 100 & 108 & 104 \\
\hline
\end{tabular}

Table.5 Yield and economics of onion in the trial

\begin{tabular}{|c|c|c|c|c|c|c|c|c|c|c|}
\hline \multicolumn{11}{|c|}{ Technology Options } \\
\hline \multirow{2}{*}{$\begin{array}{l}\text { Sl. } \\
\text { No }\end{array}$} & \multirow[t]{2}{*}{ Parameters } & \multicolumn{3}{|c|}{$\mathrm{N}-53$} & \multicolumn{3}{|c|}{ Bhima Super } & \multicolumn{3}{|c|}{ Agri Found Dark Red } \\
\hline & & $2015-16$ & $\begin{array}{c}2016- \\
17\end{array}$ & Mean & $\begin{array}{c}2015- \\
16\end{array}$ & $\begin{array}{c}2016- \\
17\end{array}$ & Mean & $\begin{array}{c}2015- \\
16\end{array}$ & $\begin{array}{c}\text { 2016- } \\
17\end{array}$ & Mean \\
\hline 1 & Total yield (q/ha) & 117 & 149 & 133 & 388 & 414 & 401 & 258 & 302 & 280 \\
\hline 2 & Gross cost (Rs/ha) & 48320 & 50230 & 49275 & 77290 & 78690 & 77990 & 51920 & 53750 & 52835 \\
\hline 3 & Gross return (Rs/ha) & 175000 & 223500 & 199250 & 388000 & 414000 & 401000 & 258000 & 261500 & 259750 \\
\hline 4 & Net return (Rs/ha) & 68680 & 173270 & 121475 & 310710 & 335310 & 323010 & 214250 & 207750 & 211000 \\
\hline 5 & $\mathrm{~B}: \mathrm{C}$ ratio & 3.63 & 4.44 & 4.04 & 5.02 & 5.26 & 5.14 & 4.12 & 4.67 & 4.39 \\
\hline
\end{tabular}

Table.6 Reactions of pest and diseases incidence of onion varieties under natural field condition

\begin{tabular}{|c|c|c|c|c|c|c|c|c|c|c|}
\hline \multicolumn{11}{|c|}{ Technology Options } \\
\hline \multirow{2}{*}{$\begin{array}{l}\text { Sl. } \\
\text { No }\end{array}$} & \multirow[t]{2}{*}{ Parameters } & \multicolumn{3}{|c|}{$\mathrm{N}-53$} & \multicolumn{3}{|c|}{ Bhima Super } & \multicolumn{3}{|c|}{ Agrifound Dark Red } \\
\hline & & $2015-16$ & 2016-17 & Mean & $2015-16$ & $2016-17$ & Mean & $2015-16$ & $2016-17$ & Mean \\
\hline 1 & Thrips incidence (\%) & 17.22 & 17.68 & 17.45 & 14.32 & 14.28 & 14.30 & 15.21 & 15.49 & 15.35 \\
\hline 2 & $\begin{array}{l}\text { Purple Leaf blotch } \\
\text { incidence }(\%)\end{array}$ & 37.26 & 38.21 & 37.73 & 13.98 & 14.48 & 14.23 & 27.54 & 28.66 & 28.10 \\
\hline 3 & $\begin{array}{l}\text { Stem phylium } \\
\text { blight }(\%)\end{array}$ & 38.22 & 39.24 & 38.73 & 15.84 & 15.62 & 15.73 & 28.88 & 29.54 & 29.21 \\
\hline 4 & $\begin{array}{l}\text { Reaction to Stem } \\
\text { phylium blight }\end{array}$ & \multicolumn{3}{|c|}{ Moderately susceptible } & \multicolumn{3}{|c|}{ Moderately resistant } & \multicolumn{3}{|c|}{ Moderately susceptible } \\
\hline
\end{tabular}

Table.7 Varietal performance and farmers feedback on various characters of Onion

\begin{tabular}{|l|l|c|c|c|c|c|c|c|c|c|}
\hline $\begin{array}{l}\text { SI } \\
\text { no. }\end{array}$ & Variety & Size & Shape & Colour & Skin & Yield & $\begin{array}{l}\text { Market } \\
\text { preference }\end{array}$ & $\begin{array}{l}\text { Availabili } \\
\text { ty of seeds }\end{array}$ & $\begin{array}{l}\text { Total } \\
\text { points }\end{array}$ & Ranking \\
\hline $\mathbf{1}$ & N-53 & 3 & 4 & 3 & 4 & 5 & 4 & 2 & 25 & III \\
\hline $\mathbf{2}$ & Bhima Super & 1 & 1 & 1 & 1 & 1 & 1 & 5 & 11 & I \\
\hline $\mathbf{3}$ & Agrifound Dark Red & 2 & 3 & 1 & 2 & 2 & 2 & 2 & 14 & II \\
\hline
\end{tabular}

\footnotetext{
Preference scale: 1-6 (1- highest preference, 6- lowest preference)
} 
The year wise economics of onion under on farm testing were estimated and results have been presented in Table 5 .

The economics analysis of data over the years revealed that Bhima Super variety recorded higher gross return (Rs. 401000/ha), net return (Rs. 323010/ha) and B:C ratio of 5.14 as compared to $\mathrm{N}-53$ and Agrifound Dark Red.

A similar better economic return by cultivation of Bhima Super variety compared to other varieties was reported by Kerure et al, (2016). The ranking of onion varieties based on the basis of farmer's feedback presented in Table 7, which indicates Bhima Super variety as the most preferred onion variety compared to Agrifound Dark Red and N-53.

The farmers perceived and ranked Bhima Super variety as the variety produced good size bulbs, attractive shape, colour of skin, better yield, good keeping quality (more shelf-life) and good consumer preference. Agrifound Dark Red was ranked second among the varieties studied. N-53 recorded the lowest preference because farmers did not appreciate its size, shape, colour, skin, lower yield and market preference along with the nature of susceptibility to stemphylium blight disease.

However, based on seed viability for current season crop production, the traditional variety $\mathrm{N}-53$ ranked one compared to other two varieties. Bhima Super ranked one in comparison to stemphylium blight disease, as it was moderately disease resistance character. Based on varietal characters and market preference, farmers rated Bhima Super as the best variety followed by Agrifound Dark Red and N-53. Similar evaluation of onion varieties for productivity performance was reported by Hiremath et al, 2018.
Hence, it can be concluded from the study that by adoption of Bhima Super variety during late Kharif season yield potentiality of onion can be exploited to a greater extent.

\section{References}

Hiremath, S.M. and Mantur, S.M. (2018). Assessment of onion varieties for late Kharif. Int. J. of Agrl. Sc.. 14:102- 105.

Kerure, P., Chandrappa, D., Salimath, S. Rudragouda, F., Chandragouda, S., Onkarappa and Gajendra, T. H. (2016). Varietal assessment in onion for higher productivity and quality. In: 1st KVK Symposium zone VIII, held at UAS, Dharwad from 21-22, January, 2016, 85 pp.

Lawande, K. E., Mahajan, Vijay Krishna, Prasad, V. S. R.and Khar, A. (2011). Bhima Super -A new red onion variety for Kharif season from DOGR. In: National Symposium on Alliums: Current scenario and emerging trends, held at Pune from 12-14 March 2011, pp. 160.

Shah et al., 2012. Comparative studies of onion cultivars at Mardan. Sarhad J. Agric. 28(3):399-402.

Sharma, S.R. 1986. Effect of fungicidal on purple blotch and bulb yield of onion. Indian Phytopathology. 39: 78-82.

Singh R. S. (1992). Disease of Vegetable Crops. Oxford and IBH Publishing Co. Pvt. Ltd. second Edition, pp. 287-289.

Tripathy, P., Priyadarshini, A, Das, S.K., Sahoo, B.B. and Dash, D.K. (2013). Evaluation of onion (Allium cepa L.) genotypes for tolerance to thrips (Thrips tabaci L.) and purple blotch [Alternaria porri (Ellis) (Iterri)]. International J. Bioresource \& Stress Mgmt., 4 (4): 561564.

Wheeler, B.E. 1969. An Introduction to Plant Diseases. John Wiley and Sons Ltd, London, UK, pp 43-46. 


\section{How to cite this article:}

Biswanath Sahoo, M. Nedunchezhiyan, Suchismita Tripathy, Kishore Sahoo, Rituparna Munshi and Madhuri Toppo. 2020. Assessment of Onion Varieties for Late kharif in NorthEastern Coastal Plain Zone of Odisha. Int.J.Curr.Microbiol.App.Sci. 9(09): 2513-2518. doi: https://doi.org/10.20546/ijcmas.2020.909.314 